\title{
Marine Brachyura (Crustacea: Decapoda: Brachyura) from the Maltese Islands and Surrounding Waters (Central Mediterranean)
}

\author{
P. J. SCHEMBRI AND E. LANFRANCO \\ Department of Mathematics and Science, The University of Malta, Msida, Malta \\ (Receited 2lsi March 1984)
}

\begin{abstract}
Based on a review of the literature and examination of several collections made in Maltese waters, 60 species belonging to 14 families of brachyuran decapods are reported from the Maltese Islands and surrounding area. Of these, 5 species are considered doubtful records in need of confirmation, while another 12 species have not been previously reported from the region. The Maltese brachyuran fauna is typical of the Central Mediterranean and shows strong affinities with that of the West Basin. A brief synopsis of the abundance, distribution and habitat preferences of the commoner species is given.
\end{abstract}

\section{Introduction}

Several works on the decapod crustaceans of the Maltese Islands have been published. The earliest appears to be that of Gulia (1858-59) who mentions 7 species of brachyuran crabs followed by a list by Medlycott (in Sedall, 1870) with 21 species. While in the latter a subjective estimate of abundance is given for each species listed, in a few cases only is information given about distribution and/or locality of capture and habitat. Gulia's (1873) list is rather more informative. This includes 36 species of marine brachyurans. Additional information, including Maltese and/or English names, some indication of abundance, distribution, habitat, notes on identification and other general notes are also given for some species. Gulia's coverage of the different species is 
rather uneven and no reference is made to Medlycott's earlier list. An account of the natural history of the Maltese Islands by Gulia's son, Giovanni (Gulia, 1889-90) includes 10 species of brachyurans, all of which were already recorded by Gulia pater. Micallef \& Evans (1968) record 29 species of brachyuran crabs in their list of the marine fauna of the Maltese Islands. Apart from the name of the species, no other information is given and no reference is made to any previous work. The most recent list is that of Stevčić (1979) who studied a collection of decapod crustaceans obtained from 8 stations off the coast of Malta ranging in depth from 5 to $145 \mathrm{~m}$. Of the 20 species found, half were brachyurans. Śtevceić appears to be only aware of Micallef \& Evans' list and consequently records some species already reported previously as new for the region.

Apart from the lists mentioned above, other works recording a limited number of species as well as a number of semi-popular articles on the brachyuran fauna of the Maltese Islands have also appeared (Despott, 1930; Lanfranco [G.], 1954, 1957, 1973; Bonnet, 1972; Agius et al. 1977; Schembri \& Jaccarini, 1978; Lanfranco [E.], 1979).

Given the scattered literature on Maltese brachyurans, the lack of cross-references in the various lists as well as the suspect identifications of some workers and recent advances in our knowledge of Mediterranean decapods, necessitating many taxonomic changes, it is clear that a revised list of Maltese brachyuran crabs is now due.

The present work attempts to provide such an updated list. Apart from reviewing and cross-referencing all previous literature on Maltese brachyuran crabs known to us and updating the nomenclature, we have also examined a substantial collection of brachyurans from the Maltese Islands and surrounding waters. This has enabled us to confirm (and in some cases refute) previous records, add new species to the Maltese list and gain some idea of the present abundance and distribution of the species. It is clear that our knowledge of the Maltese brachyuran fauna is nowhere near complete but we hope that this report will serve to highlight areas needing further study and provide a basis for future work.

\section{Material}

None of the material survives on which the older lists of Gulia (1858-59; 1873). Medlycott (in Sedall, 1870), and Micallef \& Evans (1968) were based. Inclusion of these authors' records in the present report is therefore based entirely on their published works, none of which includes illustrations. It is reported that Medlycott produced a set of colour drawings of Maltese crustaceans found by him (Gulia, 1858-59; Tallack, 1861 p. 178) but these could not be traced.

A total of 207 specimens of brachyurans collected from the Maltese Islands and surrounding waters were examined. This material included that in the authors' own collections (coded PJS and EL respectively in the species list below) and in the collections of G. Lanfranco (GL), J. L. Cilia (JLC), M. Micallef (MM) and M. Briffa (MB). Identifieations were made using published descriptions and keys while some difficult species were checked by Dr. R. W. Ingle of the British Museum (Natural History), London. Specimens marked BMNH have been deposited in the collections of this institution.

\section{Species List}

In the following list, the name of the species is followed by previous records from the Maltese Islands, material examined during the present study and comments where 
necessary, in that order. All localities reported are in the island of Malta unless otherwise stated. In the list we follow the systematic arrangement given in Zariquiey Alvarez (1968) incorporating recent nomenclatural changes as given in Ingle (1980) and Manning \& Holthuis (1981)

\section{DROMIIDAE}

Dromia personata (Linnaeus, 1758)

Dromia rumphii (Feb) [sic!]; Gulia (1858-59)

Dromia vulgaris; Medlycott (in Sedall, 1870)

Dromia vulgaris Edw.; Gulia (1873)

Dromia vulgaris; Gulia (1889-90)

Dromia vulgaris; Lanfranco (1954)

Dromia vulgaris Milne-Edwards; Micallef \& Evans (1968)

10: ex Valletta Fish Market 1954-56 (GL); 10,29: landed by fishermen at St. Julians Bay Jul. 1974 (from nets set NE Malta), leg. J. L. Schembri (PJS); 10: off Fawwara (Dingli Cliffs) 5.3.77, rocky bottom, $13 \mathrm{~m}$ (PJS); 18: off Ghar Hasan (SE Malta) 12.3.77. rocky bottom, $10 \mathrm{~m}$ (PJS).

\section{HOMOLIDAE}

Paromola cuvieri (Rissso, 1816)

Homola cuvieri Leach; Gulia (1873)

Homola cuvieri; Lanfranco (1954)

Not recorded during the present study.

Homola barbata (Fabricius, 1793)

Homola spinifrons Leach; Gulia (1873)

Homola barbata (Fabricius, 1793); Śtevčić (1979)

$1 \%$ (juv.): landed by fishermen at St. Julians Bay (date unknown) (MM): 10,2\%\%: landed by fishermen at St. Julians Bay JuL. 1974 (from nets set NE Malta), leg. J. L. Schembri (PJS).

\section{LATREILLIIDAE}

Latreillia elegans Roux, 1830

Latreillia elegans Roux, 1830; Śtevčić (1979)

Not recorded during the present study. Stevčié's specimen was collected from a depth of $110 \mathrm{~m}$ off the south coast of Malta. 


\section{DORIPPIDAE}

Ethusa mascarone (Herbst, 1785)

Ethusa mascarone Roux; Gulia (1873)

Ethusa mascarone; Lanfranco (1954)

Ethusa mascarone (Herbst); Micallef \& Evans (1968)

I0: San Anard Nov, 1976, rock bottom, $10 \mathrm{~m}$, carrying valve of Lima sp. (PJS).

Medorippe lanata (Linnaeus, 1767)

new record

10: off Fomm ir-Rih Summer 1980, $300 \mathrm{~m}$ (MM); 10 : between Malta and Filfla Is. 9.5.83, $80 \mathrm{~m}(\mathrm{MB})$; $10^{\circ}:$ Medina Bank (15 37' E:34 $\left.32^{\prime} \mathrm{N}\right) 18.8 .77$, mud, $70-100 \mathrm{~m}$ (PJS); 16,19: $96 \mathrm{~km}$ SE of Lampedusa Is. 21-26.8.77, mud, $100 \mathrm{~m}$ (PJS).

\section{CALAPPIDAE}

Calappa granulata (Linnaeus, 1758)

Calappa cristata (M.Ed.); Medlycott (in Sedall, 1870)

Calappa granutata Fabr. [sic!]; Gulia (1873)

Calappa granulata; Lanfranco (1954)

Calappa granulata (L.); Micallef \& Evans (1968)

Calappa granulata L.; Lanfranco (1979)

10: ex Valletta Fish Market 1954-56 (GL); 10: of Fomm ir-Rif Summer 1980, $300 \mathrm{~m}$ (MM); $2 \delta^{\circ}: 3 \mathrm{~km}$ E of Gozo Is. 12.4.83, $80 \mathrm{~m}$ (MB); $10^{\circ}$ : between Malta and Filfla Is. 9.5.83, $80 \mathrm{~m}$ (MB); 10: landed by fishermen at St. Julians Bay Summer 1974, leg. B. Warrington (EL); 2 specimens (chelae only): landed by fishermen at St. Julians Bay May 1974 (from nets set NE Malta), leg. J. L. Schembri (PJS); 10': off Marfa 29.2.76, $165 \mathrm{~m}$ (PJS).

The specimen from between Malta and Filfla Is. was much like the 'southern form' of C. granulata described by Bouvier (1940 p. 204).

\section{LEUCOSIIDAE}

Ilia nucleus (Linnaeus, 1758)

Ilia rugosula (M.Ed.); Medlycott (in Sedall, 1870)

Ilia nucleus Leach [and] I. rugosula Leach; Gulia (1873)

Ilia nucleus; Lanfranco (1954)

Ilia nucleus (Herbst); Micallef \& Evans (1968) 
10: Dahlet il-Fekruna 22.8.74, mud, $3 \mathrm{~m}$ (PJS); 1 specimen (chela only): Mistra Bay 20.7.80, gravel, $2 \mathrm{~m}$ (PJS).

Ilia rugosula Risso, 1826 reported by Gulia (1873) is considered a mere variety of $I$. nucleus (Bouvier, 1940; Zariquiey Alvarez, 1968).

Ebalia spp.

Seguin (1968) records zoea larvae of Ebalia from plankton samples taken in Maltese waters but does not identify the species.

Ebalia tuberosa (Pennant, 1777)

Ebalia tuberosa (Pennant, 1777); Śtevčić (1979)

Not recorded during the present study. Śtevčićs specimen was collected from a depth of $75 \mathrm{~m}$ off the south coast of Malta.

Ebalia edwardsi Costa, 1838

new record

19: Wied iż-Żurrieq 10.8,77, in sediment on cave floor, $22 \mathrm{~m}$ (PJS).

\section{PIRIMELIDAE}

Pirimela denticulata (Montagu, 1808)

Pirimela denticulata; Medlycott (in Sedall, 1870)

Pirimela denticulata Leach; Gulia (1873)

Pirimela denticulata (Mont.); Micallef \& Evans (1968)

10: Exiles (Sliema) Aug. 1975 (EL); 2 specimens (damaged): washed ashore at Xatt 1-

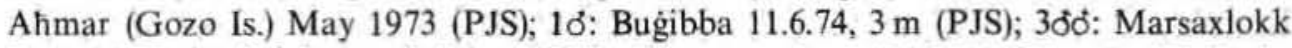
Bay 6.4.77, buried in sand, $0.1 \mathrm{~m}$ (PJS); 10: same data (BMNH) [det. R. W. Ingle, 1977].

Sirpus zariquieyi Gordon, 1953

new record

10: Santa Marija Bay (Comino Is.) 18.6.77, $5 \mathrm{~m}$ (PJS); 10: St. Paul's Bay 5.8.83, on fouling community on submerged buoy, $2 \mathrm{~m}$ (PJS).

PORTUNIDAE

Carcinus aestuarii Nardo, 1847

Carcinus maenas Leach; Gulia (1858-59)

Carcinus menas (Leach) [síc!]; Medlycott (in Sedall, 1870)

Carcinus maenas Leach; Gulia (1873) 
Carcinus moenas [sic!]; Gulia (1889-90)

Carcinus maenas; Lanfranco (1954)

Carcinides maenas Rathke; Micallef \& Evans (1968)

Carcinides maenas; Bonnet (1972)

Carcinus mediterraneus Czerniavsky; Agius et al. (1977)

Carcinides mediterraneus (Czerniavsky); Lanfranco (1979)

200: Marsaxlokk 1.8.73 (GL); $200^{\circ}, 1$ : : Malta (no other data) (GL); 10: ditto (JLC); 1 specimen (carapace only): ditto, leg. J. Sciberras (PJS); 1 6,1 : $:$ Marsamxett Harbour near Manoel Island 1973 (PJS)

Until the late 1950's, only one species of Carcinus, C. maenas (Linnaeus, 1758) was recognized. However detailed investigations of Atlantic and Mediterranean populations assigned to this species showed that in actual fact two taxa were present. Holthuis \& Gottlieb (1958) have shown that Linnaeus' description was based on Atlantic specimens and therefore the name maenas should be retained for the Atlantic species of Carcinus. These authors further proposed the name $C$. mediterraneus Czerniavsky, 1884 for the Mediterranean species of Carcinus, this being the oldest available one known to them. This nomenclature has been in use until recently when it was pointed out by Manning \& Holthuis (1981) that mediterraneus is a junior synonym of C. aestuarii Nardo, 1847. All Maltese records of C. maenas and C. mediterraneus therefore refer to $C$. aestuarii.

Portumnus latipes (Pennant, 1777)

Platyonichus latipes Edw.; Gulia (1873)

Platyonicus latipes [sic!]; Lanfranco (1954)

Not recorded during the present study. Gulia (1873) gives the following synonyms for this species: $"=$ Portunus depurator Latr. Cancer ranipes Barrel. Cancer depurator Scop.". Both P.depurator and C.depurator refer to Liocarcinus depurator, a species also recorded by Gulia and not to Portumnus latipes.

\section{Liocarcinus spp.}

The genus Macropipus has been recently redefined by Ingle (1980) and the bulk of the species previously included in this genus are now placed in the genus Liocarcinus (see also Manning \& Holthuis, 1981).

Liocarcinus arcuatus (Leach, 1814)

Portunus arcuatus; Medlycott (in Sedall, 1870)

10: Ta' Kanini (Mellieha Bay) Jan. 1976, $12 \mathrm{~m}$ (PJS); 1 specimen (carapace only): Mistra Bay 20.7.83, $2 \mathrm{~m}$ (PJS).

In view of the consistent morphological differences between Atlantic and Mediterranean populations of this species. Zariquiey Alyarez (1968) considers the Mediterranean populations to be a distinct subspecies: L. arcuatus rondeletii (Risso, 1816). 
Liocarcinus puber (Linnaeus, 1767)

Portunus puber Leach; Gulia (1873)

Portunus puber; Gulia (1889-90)

Portumus puber; Lanfranco (1954)

Not recorded during the present study.

Liocarcinus corrugatus (Pennant, 1777)

Portunus corrugatus (Leach); Gulia (1858-59)

Portunus corrugatus; Medlycott (in Sedall, 1870)

Portunus corrugatus Leach; Gulia (1873)

Portunus corrugatus; Lanfranco (1954)

Portunus corrugatus (Penn.), Micallef \& Evans (1968)

16: Malta (no other data) (GL); 10: landed by fishermen at Marsaxlokk 1978 (MM): 18: Malta (no other data) (PJS); 10: landed by fishermen at St. Julians Bay 24.4.74 (from nets set NE Malta), leg. J. L. Schembri (PJS).

Liocarcinus zariquieyi (Gordon, 1968)

new record

10: Wied ix-Xaqqa $31.5 .77,7 \mathrm{~m}$ (PJS)

(?) Liocarcinus bolivari (Zariquiey Alcarez, 1948)

new record (?)

1 ( (juv.): Dahlet il-Fekruna 14.7.83, $8 \mathrm{~m}$ (PJS)

The only specimen studied was damaged and lacked the pereiopods thus making definite identification difficult. The carapace characters, however, agree well with the description of $L$. bolivari as given in Zariquiey Alvarez (1968) as does the colour pattern. This species has for a long time been confused with $L$. depurator which it closely resembles. Medlycott's record (in Sedall, 1870) of "Portunus (?) A species nearly allied to $P$. depurator" may well be the present species.

Liocarcinus depurator (Linnaeus, 1758)

Portunus plicatus Risso; Gulia (1873)

Portunus depurator; Lanfranco (1954)

Portunus depurator (L.); Micallef \& Evans (1968)

19: Mellieha Bay 4.3.73 (GL); 300: Malta (no other data) (JLC); 19: between Malta and Filfla Is. 9.5.83, $80 \mathrm{~m}(\mathrm{MB}) ; 18,1$ incomplete specimen: Mellieha Bay 19.7.73, sand (PJS); 10: Exiles (Sliema) Jun. 1974, sand (PJS)

Macropipus tuberculatus (Roux, 1830)

new record

1.0: Medina Bank (15 37'E:34 32'N) 18-20.8.77, mud, 70-100 m (PJS); $400,2909: 96 \mathrm{~km}$ SE of Lampedusa Is. 21-26.8.77, mud, $100 \mathrm{~m}$ (PJS); $2 \delta^{\circ}$ : same data, (BMNH) [det. R. W. Ingle, 1977] 
Polybius henslowi Leach, 1820

Polybius henslowi Leach; Despott (1930)

Polybius Henslowii; Lanfranco (1954)

Not recorded during the present study.

Bathynectes longipes (Risso, 18/6)

Portunus longipes Risso; Gulia (1873)

Portunus longipes; Lanfranco (1954)

Portunus longipes (Risso); Micallef \& Evans (1968)

Not recorded during the present study.

Callinectes sapidus Rathbun, 1896

200: Marsaxlokk Bay 20.11.72, trapped by 'nassa' (basketwork trap) at $8 \mathrm{~m}$ (G. Zammit Maempel personal communication)

This species is native to the east coast of America but has been introduced into European Atlantic coastal waters and the Mediterranean (see Holthuis \& Gottlieb. 1958). The two Maltese specimens were purchased by the National Museum of Natural History, Mdina, Malta and are currently on exhibit there.

Portunus hastatus (Linnaeus, 1767)

Lupea hastata Edw.; Gulia (1873)

Lupa hastata; Lanfranco (1954)

Neptunus hastatus L; Micallef \& Evans (1968)

16: Comino Is, 1958- 60 (GL)

\section{XANTHIDAE}

Pilumnus spinifer H. Milne-Edwards, 1834

Pilumnus spinifer (M.Ed.); Medlycott (in Sedall, 1870)

Pilumnus spinifer H. Milne-Edwards, 1834; Śtevčić (1979)

10: between Malta and Filfla Is. 9.5.83, $80 \mathrm{~m}(M B) ; 19: 96 \mathrm{~km}$ SE of Lampedusa Is. 2126.8.77, mud, $100 \mathrm{~m}$ (PJS) [det. R. W. Ingle, 1977]

Pilumnus villosissimus (Rafinesque, 1814)

Pilumnus villosus Risso; Gulia (1873)

Pilumnus hirtellus (L.); Agius et al. (1977)

19: Malta (no other data) (PJS); 10: Dahlet il-Fekruna 18.7.74 (PJS); 19: Marsaxlokk Bay 23.3.76, rocky bottom, $3 \mathrm{~m}$ (PJS) [det. R. W. Ingle, 1977]; 10: Mistra Bay 26.3.76. on fouling community on submerged buoy, $3 \mathrm{~m}$ (PJS)

The specimens on which the record of P. hirtellus by Agius et al. (1977) was based have 
been re-examined and found to belong to the present species (R. W. Ingle, personal communication).

(?) Pilumnus hirtellus (Linnaeus, 1761)

Pilumnus hirtellus (L.); Micallef \& Evans (1968)

Not recorded during the present study. Since all shallow water Pilumnus collected from the Maltese Islands, including the ' $P$. hirtellus' of Agius et al. (1977) (see above) were $P$. villosissimus, and since the source of identification used by Micallef \& Evans (1968) does not differentiate between $P$. hirtellus and its Mediterranean cogeners, these authors' record of $P$. hirtellus must be regarded as unconfirmed pending collection of further material of this species.

Paragalene longicrura (Nardo, 1868)

Paragalene longicrura Staz. Zool.; Despott (1930)

Paragalene longicrura; Lanfranco (1954)

Not recorded during the present study.

Eriphia verrucosa (Forskal, 17万)

Eriphia spinifrons (Lat.); Gulia (1858-59)

Eriphia spinifrons; Medlycott (in Sedall, 1870)

Eriphia spinifrons Savigny; Gulia (1873)

Eriphia spinifrons (Herbst); Micallef \& Evans (1968)

Eriphia spinifrons; Bonnet (1972)

Eriphia verrucosa Forsk.; Lanfranco (1979)

10: Malta (no other data) (GL); 18: Exiles (Sliema) Summer 1971 (EL); $20^{\circ}$ : Manoel Island 1971 (EL); 1 specimen (incomplete): Malta (no other data) (PJS); 19: Kalkara Creek Oct. 1973 (PJS); 19: Birzebbuga 13.4.75 (PJS); 1 specimen (carapace only): Mistra Bay 20.7.83, $2 \mathrm{~m}$ (PJS)

\section{Xantho spp.}

Prior to Drach \& Forest's (1953) review of the systematics of European species of $X$ antho, there was much confusion in the literature as to the correct nomenclature of these crabs. Three Mediterranean species are currently recognized: $X$. poressa (Olivi, 1972); X. pilipes A. Milne-Edwards, 1867; and $X$. incisus (Leach, 1814) represented in the Mediterranean by the subspecies granulicarpus (Forest, 1953), the nominal subspecies being restricted to the Atlantic. It is difficult to assign the older Maltese records of Xantho to the correct species, mainly because of the confused synonymy of the group. In drawing up the lists below we have followed the synonymy as given by Zariquiey Alvarez (1968). This problem is discussed further below.

Gulia (1889-90) records two species of Xantho without giving specific names. It is likely that this author was referring to the same two species as in his father's list (Gulia, 1873) (see below under Xantho poressa).

\section{Xantho poressa (Olivi, 1792)}

Xantho rivulosus (M.Ed.); Medlycott (in Sedall, 1870) 
$X$ antho floridus Leach $=$ Cancer poressa Olivi [and] $X$ antho rivulosus Risso. Edw. $=X$. florida var. b. Leach; Gulia (1873)

$X$ antho rivulosa; Lanfranco (1954)

Xantho hydrophilus (Herbst); Micallef \& Evans (1968)

Xantho hydrophilus; Bonnet (1972)

Xantho hydrophilus (Herbst) $(=X$. rivulosus Risso); Lanfranco (1979)

10: Malta (no other data) (GL); 19: St. Thomas Bay 18.8.66 (GL); 200: Bahar icCaghaq 2.8 .72 (GL); $1 \delta, 1$ (juv.): Malta (no other data) (JLC); 1ᄋ: Exiles (Sliema) Summer 1971 (EL); 200,1 incomplete specimen: Malta (no other data) (PJS); 10: Dahlet il-Fekruna Aug. 1973 (P.JS); 1 specimen (incomplete): St. Paul's Bay 23.8.74, under rocks, $1 \mathrm{~m}$ (PJS); 16: Marsaxlokk Bay 22.3.76, under rocks, $3 \mathrm{~m}$ (BMNH) [det. R. W. Ingle, 1977]; 16: Marsaxlokk Bay 6.4.77, 0.1 m (BMNH) [det. R. W. Ingle, 1977]; $20^{\circ}$ : Mistra Bay 5.7.78 (PJS); 10: Marsa Aug. 1980, leg. G. Bonnet (PJS); 2 specimens (carapace only): Mistra Bay 20.7.83, 2 m (PJS)

Gulia (1873) records two species of Xantho from the Maltese Islands giving them as reproduced above. Although both species as named by Gulia translate to what is currently called Xantho poressa (Olivi), it is quite likely that one of the species reported by this author is actually $X$. incisus granulicarpus (Forest), the other common Maltese species of the genus (see below).

Zariquiey Alvarez (1968) hesitantly synonymizes Cancer hydrophilus Herbst, 1790 with Xantho pilipes Milne-Edwards, 1867 although other authors consider Herbst's species synonymous with $X$. poressa (Olivi) (e.g. Holthuis \& Gottlieb, 1958). Reference to the original source of identification used by Micallef \& Evans (1968) reveals that these authors' record of $X$. hydrophilus refers to the present species, not $X$. pilipes and similarly Bonett's (1972) and Lanfranco's (1979) records.

\section{Xantho incisus granulicarpus (Forest, 1953)}

Xantho florida; Lanfranco (1954)

Xantho floridus (Mont.); Micallef \& Evans (1968)

Xantho incisus granulicarpus (Forest); Schembri \& Jaccarini (1978)

1 specimen (carapace only): Mellieha Bay Sept. 1975 (PJS); 1 specimen (incomplete): Malta (no other data) (PJS); 10: Dahlet il-Fekruna 20.7 .73 (PJS); 1 specimen (incomplete): Mellieha Bay Reef 25.8 .73 (PJS); 18: Mellieha Bay Apr. 1974 (PJS); 10: Exiles (Sliema) 25.6.74, leg. S. P. Schembri (PJS); 1 specimen (incomplete): Marsascala Jul. 1974, $5 \mathrm{~m}$ (PJS); 10: Dahlet il-Fekruna 27.7.74, $2.5 \mathrm{~m}$ (PJS); 19: Marsaxlokk Bay 3.10.75, in rock burrows of Upogebia deltaura, 3 m (PJS) [det. R. W. Ingle, 1977]; 10: Marsaxlokk Bay 23.3.76, in rock burrows of Upogebia deltaura, $3 \mathrm{~m}$ (BMNH) [det. R. W. Ingle, 1977]; 1 specimen (carapace only): Mistra Bay 20.7.83, $2 \mathrm{~m}$ (PJS).

This species may also have been reported by Gulia (1873) (see above under $X$. poressa).

\section{Paractaea rufopunctata (H. Milne-Edwards, 1834)}

new record

1 specimen (cheliped only): Tigne 30.9 .82 (EL); 1 \&: Qawra 14.3.76, under rocks; $5 \mathrm{~m}$ (PJS); 1 specimen (incomplete): Wied iż-Żurrieq 10.8.77, in sediment on cave floor, $22 \mathrm{~m}$ (PJS) 


\section{PINNOTHERIDAE}

Gulia (1858-59) records "Pinnotheres" without identifying the species.

Pinnotheres pisum (Linnaeus, 1767)

Pinnotheres pisum Latr.; Gulia (1873)

Pinnotheres pisum; Lanfranco (1954)

Not recorded during the present study.

Pinnotheres pinnotheres (Linnaeus, 1758)

Pinnotheres veterum Edw.; Gulia (1873)

Pinnotheres veterum; Lanfranco (1954)

Pinnoteres pinnoteres (L.); Micallef \& Evans (1968)

Not recorded during the present study.

\section{GONEPLACIDAE}

Goneplax rhomboides (Linnaeus, 1758)

Gonoplax angulata Edw.; Gulia (1873)

Gonoplax rhomboides [and] G. angulata; Lanfranco (1954)

Gonoplax angulata (Penn.); Micallef \& Evans (1968)

1 specimen (juv.): off Fomm ir-Rih Summer 1980, $300 \mathrm{~m}$ (MM); 18 : Medina Bank $\left(15^{\circ} 37^{\prime} \mathrm{E}: 34^{\circ} 32^{\prime} \mathrm{N}\right)$ 18-20.8.77, mud, 70-100 m (PJS); 10: $96 \mathrm{~km}$ SE of Lampedusa 1s. 21-26.8.77, mud, $100 \mathrm{~m}$ (PJS)

Two forms of this species exist in the Mediterranean. In one of these there is an additional tooth behind the anterolateral tooth of the carapace $[=G$. angulata (Pennant, 1777)] and in the other none, or only a small tubercle $[=G$. rhomboides (Linnaeus, 1758)]. These are considered by some to be distinct species or subspecies although all intermediate stages between the two extremes are present (Bouvier, 1940; Zariquiey Alvarez, 1968). In the specimens examined during the present study the second tooth is either absent or at most is represented by a small tubercle, therefore all fall within the taxon rhomboides whatever its status. Gulia (1873) however reports both forms (as " $G$. bispinosa Leach" $[=G$. angulata $]$ and "G. rhomboides Desm") as being found in Maltese waters, as does Lanfranco (1954).

\section{GRAPSIDAE}

Pachygrapsus marmoratus (Fabricius, 1787)

Grapsus varius; Medlycott (in Sedall, 1870)

Grapsus varius Latr.; Gulia (1873)

Grapsus varius; Gulia (1889-90)

Pachygrapsus marmoratus; Lanfranco (1954) 
Pachygrapsus marmoratus (Fabr.); Micallef \& Evans (1968)

Pachygrapsus marmoratus; Bonnet (1972)

Pachygrapsus marmoratus Fabr.; Lanfranco (1979)

3đơ: Fond Ghadir (Sliema) 12.8.66 (GL); 19: Manoel Island 29.7.73, with Sacculina (GL); 18: Grand Harbour 21.12.73 (GL); 18,6९\%,3 specimens (juv.): Malta (no other data) (JLC); 10: Sliema Summer 1971 (EL); 10,29\%: Dahlet il-Fekruna 1973, shore (PJS); 19,1 specimen (juv.): Birzebbuga 13.4.75, shore (PJS)

Planes minutus (Linnaeus, 1758)

New record

10: Marsaxlokk 6.4.77, stranded in rockpool (PJS)

Crabs of the genus Planes are pelagic, being found mainly on floating weed but also on other floating objects and on marine turtles. The specimen from Marsaxlokk was obviously stranded on the shore perhaps following beaching of the flotsam with which it was originally associated.

Costa (1982) has recently reported the presence of Planes cyaneus Dana, 1851 in the Mediterranean, identified on the morphometric and morphological criteria of Chace (1951). These criteria were also applied to the single specimen collected from Malta. In terms of carapace length $(17.0 \mathrm{~mm})$ and carapace width $(16.9 \mathrm{~mm})$ and their ratio, the Maltese specimen is intermediate between $P$. minutus and $P$. cyaneus. In terms of the ratio of the length of the three distal segments of the 2 nd walking legs to carapace length $(=0.91)$ it is closer to $P$. minutus (range $0.83-1.07$ ) than to $P$. cyaneus (range $0.68-0.89$ ). In terms of the morphology of the abdomen and especially the terminal segment, the Maltese specimen is closer to $P$. cyaneus.

In view of the rather marginal differences between these two species of Planes, the intermediate characters of the only specimen available for study and the lack of information about variability in Central Mediterranean populations of Planes, together with the fact that Costa (1982) has reported P. cyaneus from the Mediterranean on the basis of 3 specimens also showing rather intermediate characters, we feel that it is best to regard the Maltese Planes as $P$. minutus pending study of a larger number of specimens.

\section{PARTHENOPIDAE}

Parthenope angulifrons (Latreille, 1825)

Lambrus angulifrons Edw.; Gulia (1873)

Lambrus angulifrons (Latr.); Micallef \& Evans (1968)

Lambrus angulifrons Latr.; Lanfranco (1973)

Lambrus angulifrons Latr.; Lanfranco (1979)

18: Malta (no other data) (GL); 10: Marsamxett Harbour 1960 (GL)

Parthenope macrochelos (Herbst, 1790)

Lambrus mediterraneus Roux; Gulia (1873) 
10ँ: off Fomm ir-Rih Summer 1980, $300 \mathrm{~m}$ (MM); 19:96 km SE of Lampedusa Is. 2126.8.77, mud, $100 \mathrm{~m}$ (PJS)

Parthenope massena (Roux, 1830)

Lambrus Massena Roux; Gulia (1873)

Lambrus massena Roux; Micallef \& Evans (1968)

Not recorded during the present study.

\section{MAJIDAE}

Maja squinado (Herbst, 1788)

Maia squinado (Lamk.); Gulia (1858-59)

Maia squinado; Medlycott (in Sedall, 1870)

Maia squinado Latr.; Gulia (1873)

Maja squinado; Gulia (1889-90)

Maia squinado; Lanfranco (1954)

Maia squinado (Herbst); Micallef \& Evans (1968)

Maia squinado Herbst; Lanfranco (1979)

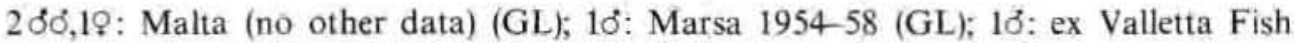
Market 1954 (GL); 18: Sliema 1971 (EL)

The largest specimen studied (male from Valletta Fish Market: carapace length, $15.1 \mathrm{~cm}$; rostral spine length, $2.2 \mathrm{~cm}$; carapace width, $12.7 \mathrm{~cm}$ ) agrees well with the description and morphometry of M. squinado as given in Bouvier (1940) and Zariquiey Alvarez (1968). The other specimens were much smaller and although these also agreed well with the published descriptions of $M$. squinado, they were closer to $M$. crispata with respect to the ratio of rostral length to total carapace length than to the present species.

Maja crispata (Risso, 1827)

Maia verrucosa (M.Ed.); Medlycott (in Sedall, 1870)

Maia verrucosa Milne Edw.; Gulia (1873)

Maia verrucosa; Lanfranco (1954)

Maia verrucosa Milne-Edwards; Micallef \& Evans (1968)

Maia verrucosa; Bonett (1972)

Maia verrucosa Milne-Edwards; Lanfranco (1979)

1 specimen (incomplete): landed by fishermen at Il-Prajjet (Anchor Bay) 30.8 .73 (PJS); 10: landed by fishermen at St. Julians Bay May 1974 (from nets set NE Malta), leg. J. L. Schembri (PJS); 10: Exiles (Sliema) 26.7.74, $2.5 \mathrm{~m}$, leg. S. P. Schembri (PJS); 10: Dahlet il-Fekruna 27.7.74, rocky bottom, $1 \mathrm{~m}$ (PJS)

Pisa spp.

There is much confusion in the older literature on Mediterranean species of Pisa. The $P$. tetraodon of older authors has been split into three separate species: $P$. tetraodon s.str., P. muscosa (Linnaeus, 1758) and $P$. corallina (Risso, 1816) (Holthuis \& Gottlieb, 
1958). Apart from these, another three species are also known from the Mediterranean (Zariquiey Alvarez, 1968). Because of these taxonomic changes, the older Maltese records of Pisa spp. are considered unreliable.

Pisa tetraodon (Pennant, 1777)

Pisa tetraodon [and] Pisa hirticornis (Herbst); Medlycott (in Sedall, 1870)

Pisa tetraodon Leach; Gulia (1873)

Pisa tetraodon; Lanfranco (1954)

Pisa tetraodon Penn.; Micallef \& Evans (1968)

Pisa tetraodon Penn.; Lanfranco (1979)

400,19: Grand Harbour Aug. 1958 (GL); 200\%: Fond Ghadir (Sliema) (date not known) (GL); 200 : St. Julians Bay (date not known) (MM); 1 specimen (carapace only): Tigne 30.9.82 (EL); 10,18: Malta (no other data), leg. R. Agius (PJS); 10,18: landed by fishermen at St. Julians Bay May 1974 (from nets set NE Malta), leg. J. L. Schembri (PJS); 19: Marsaxlokk Bay 6.4.77, 0.1 m (BMNH) [det. R. W. Ingle, 1977]

(?) Pisa corallina (Risso, 1816)

Pisa corallina Edw.; Gulia (1873)

Pisa corallina; Micallef \& Evans (1968)

Not recorded during the present study. Maltese records of this species may actually refer to other species of Pisa and are to be confirmed.

Pisa muscosa (Linnaeus, 1758).

new record

18: Malta (no other data) (PJS); 1 specimen (carapace only): Mistra Bay 20.7.83, $2 \mathrm{~m}$ (PJS)

Pisa nodipes (Leach, 1815)

New record

19: Il-Barranija (24 km off SE Malta) Winter 1981, $100 \mathrm{~m}$ (MM); 10: $3 \mathrm{~km}$ E of Gozo Is. $26.4 .83,82 \mathrm{~m}(\mathrm{MB}) ; 10$ : between Malta and Filfla Is. $9.5 .83,80 \mathrm{~m}(\mathrm{MB}): 200$ : Malta (no other data) (PJS); 10: landed by fishermen at St. Julians Bay Jun. 1974 (from nets set NE Malta), leg. J. L. Schembri (PJS); 1ㅇ: Malta 1975 (PJS)

(?) Pisa armata (Latreille, 1803)

Lissa armata; Micallef \& Evans (1968)

Not recorded during the present study and to be confirmed.

Herbstia condyliata (Fabricius, 1787)

Herbstia condyliata (M.Ed.); Medlycott (in Sedall, 1870)

Herbstia condyliata Edw.: Gulia (1873)

1 specimen (juv.): Malta (no other data) (MM); 10: Malta (no other data) (PJS): 10: 
landed by fishermen at St. Julians Bay May 1974 (from net set NE Malta), leg. J. L. Schembri (PJS)

Lissa chiragra (Fabricius, 1775)

Lissa chiragra Leach; Gulia (1873)

Lissa chiragra; Lanfranco (1954)

Lissa chiragra (Herbst); Micallef \& Evans (1968)

Lissa ciragra [sic!]; Bonett (1972)

Lissa chiragra (Fabricius, 1775): Śtevčić (1979)

10: landed by fishermen at St. Julians Bay May 1974 (from nets sêt NE Malta), leg. J.

L. Schembri (PJS)

Eurynome aspera (Pennant, 1777)

Eurynome scutellatus (Risso): Gulia (1858-59)

Eurinome aspera: Medlycott (in Sedall, 1870)

Eurınome aspera (Pennant, 1777); Śtevčić (1979)

Not recorded during the present study.

Acanthonyx lunulatus (Risso, 1816)

Acanthonyx lanulatus (M.Ed.): Medlycott (in Sedall. 1870)

Acanthonyx lunulatus Latr.; Gulia (1873)

Acanthonyx lunulatus: Gulia (1889 90)

Acanthonıx lumulatus (Risso); Micallef \& Evans (1968)

Acanthonyx lumulatus (Risso); Lanfranco (1979)

300: Fond Ghadir (Sliema) Jul. 1974 (GL); 10: Malta (no other data) (JLC); 1: Exiles (Sliema) Summer 1971 (EL); 200,290: St. Georges Bay (Birżebbugá) 9.6.74. on Cistoseira sp. just below water level (PJS)

Inachus sp. [(?) dorsettensis (Pennant, 1777)]

Inachus dorsettensis (Pennant, 1777); Śtevc̉ič (1979)

Not recorded during the present study. Manning \& Froglia (1982) have recently separated Mediterranean ' $I$. dorsettensis' into two taxa: $I$. dorsettensis s. str. and $I$. partirostris (Risso, 1816). The latter is a deep water species (>90 m), smaller and more slender than I. dorsettensis s. str. In light of this, records of ' $I$. dorsettensis' from deep water, including those of Śtevěić (1979) from Maltese waters, need to be re-examined.

Inachus thoracicus (Roux, 1830)

Inachus thoracicus (M.Ed.); Medlycott (in Sedall, 1870)

Inachus thoracicus Roux; Gulia (1873)

Inachus thoracicus Roux; Micallef \& Evans (1968)

Inachus thoracicus Roux, 1830; Śtevẻić (1979)

200: landed by fishermen at Marsaxlokk 1978 (MM); $10,3 \%$ : $3 \mathrm{~km} \mathrm{E}$ of Gozo Is., $82 \mathrm{~m}(\mathrm{MB})$ 
Achaeus cranchii Leach, 1817; Śtevčić (1979)

Not recorded during the present study. Stevčić's specimen was collected from a depth of $75 \mathrm{~m}$ off the south coast of Malta.

Achaeus gordonae Forest \& Zariquiey Altarez, 1955

new record

10,18: Bugibba 11.6.74, on weed, $2 \mathrm{~m}$ (PJS)

\section{Macropodia spp.}

Five species of Macropodia are currently known to inhabit the Mediterranean (Zariquiey Alvarez, 1968). Since some of these were only recognized as distinct species after the publication of some of the Maltese lists, or after publication of the sources of identification used to compile these lists, the older Maltese records must be considered unreliable as they may refer to species other than those actually listed.

Gulia (1889-90) records two species of "Steuor ynchus" [sic!] without giving specific names. It is likely that this author was referring to the same two species recorded in his father's list (Gulia, 1873) (see below under Macropodia longirostris).

Lanfranco (1954) records "Stenorynchus phalangium" without giving an authority. Since the specific name phalangium has been applied to different species by different authors, the identity of Lanfranco's species cannot be ascertained.

(?) Macropodia rostrata (Linnaeus, 1761)

Macropodia rostrata (L.); Micallef \& Evans (1968)

Not recorded during the present study. Since the source of identification used by Micallef \& Evans (1968) does not include all the species of Macropodia currently known from the Mediterranean and since theirs is the only record from Maltese waters, $M$. rostrata has to be confirmed for the region.

Macropodia czerniavskii (Brandt, 1880)

new record

1 specimen: landed by fishermen at Marsaxlokk 1978 (MM); 10: Malta (no other data) (PJS)

Macropodia linaresi Forest \& Zariquiey Alvarez, 1964

Macropodia linaresi Forest et Zariquiey Alvarez, 1964; Śtevčic̉ (1979)

Not recorded during the present study.

Macropodia longirostris (Fabricius, 1775)

Stenorynchus longirostris (M.Ed.); Medlycott (in Sedall, 1870)

Stenorynchus aegyptīus Edwards = S.phalangium Audouin [and] Stenorynchus longirostris Edwards; Gulia (1873) 
Not recorded during the present study, Holthuis \& Gottlieb (1958) report that a syntype of Stenorynchus aegyptius H. Milne-Edwards, $1834(=S$. phalangium Savigny \& Audouin, 1826) examined by them proved to be Macropodia longirostris (Fabricius, 1775). Gulia's (1873) record of $S$. aegyptius is therefore included with the present species.

\section{Discussion}

To date, 60 species of brachyuran crabs are known from the Maltese Islands and surrounding waters. Twelve of these are recorded here for the first time while another 16 previously reported species have not been met with during the present study. Of the 60 species listed, 5 are considered doubtful records pending confirmation.

Some 115 brachyuran crabs are known from the Mediterranean Sea of which approximately 13 species are recent immigrants from the Red Sea via the Suez Canal. A few other species have been introduced accidentally from elsewhere but only one of these, Callinectes sapidus, seems to have established itself in the Mediterranean where it is known from scattered localities in both the West and East Basins, and now from the Maltese Islands. None of the Red Sea immigrant species have reached the Central Mediterranean as yet.

Not counting immigrants, some $58 \%$ of all Mediterranean species also occur in Maltese waters. This high proportion of occurrences is hardly surprising considering the central position of the Islands and that some $86 \%$ of indigenous Mediterranean brachyurans are found throughout the Mediterranean, only few species being restricted to a particular region of this sea. However, the affinities of the Maltese brachyuran fauna are clearly closer to that of the West Basin than to that of the eastern Mediterranean. Of those indigenous species known only from the western half of the Mediterranean, some $44 \%$ (4 species) occur also in Maltese waters whereas none of the exlcusively eastern Mediterranean indigenous species occur around the Maltese Islands. Moreover, for another 5 West Basin/Maltese species, the only East Basin records to date are from the Adriatic Sea and environs. No detailed biogeographical analysis of the Mediterranean brachyuran fauna is possible at present however, given the uncertainty of many older records and the paucity of our knowledge of the fauna of all but a few areas in the region.

A review of the available literature on Maltese brachyurans and the authors' own field observation's allow a few general remarks to be made on the abundance, distribution and habitat preferences of the commoner species within the Maltese Islands.

There are no supralittoral crabs per se in the Maltese Islands although the very abundant Pachygrapsus marmoratus of rocky shores is frequently found supralittorally in calm weather. Also on rocky shores and in calm weather, Eriphia verrucosa is found in the uppermost regions of the mediolittoral but this crab retreats to deeper water in rough weather. On lower mediolittoral/upper infralittoral algae, principally $C$ ystoseira spp., are found large populations of Acanthonyx lumulatus clinging to the fronds.

On soft substrata in the upper infralittoral Carcinus aestuarii is common on mud or fine sand while Liocarcinus arcuatus and Pirimela denticulata are both common on coarser sand in which they bury themselves. The last named occurs in quite shallow 
water and occasionally in the sediment at the bottom of rock-pools. Also buried in the sediment but in deeper water are found a number of other species. liocarcinus depurator is found on middle infralittoral sand while Ilia nucleus apparently prefers coarser material. Species of Ebalia are found in the lower infralittoral while Calappa granulata is common in coarse sand and gravel in the same depth zone but also circalittorally. Goneplax rhomboides constructs burrows in lower infralittoral and upper circalittoral mud while Medorippe lanata is found on circalittoral mud. Other species found on soft substrata are the middle infralittoral Parthenope angulifrons, the lower infralittoral Inachus thoracicus and the circalittoral Parthenope macrochelos and Macropipus tuberculatus, all on fine sand or mud.

A number of species are found on mixed bottoms. These include Ethusa mascarone, Liocarcinus corrugatus and the two species of Maja in the upper to middle infralittoral and Lissa chiragra, Herbstia condyliata (both mainly on coralligenous bottoms) and Macropodia czerniauskii in the lower infralittoral. Both species of Maja are common, M. crispata being found in shallower water than M. squinado. Pisa muscosa is found in the middle infralittoral while $P$. tetraodon is found in the same region mainly in or round Posidonia praries. P. nodipes occurs in the lower infralittoral and extends into the circalittoral while Pilumnus spinifer, Homola barbata and the rare Latreillia elegans are circalittoral species.

On hard bottoms, Achaeus gordonae is found on weed in the upper infralittoral, Sirpus zariqueyi is also found on weed in the same region and in deeper water while Xantho poressa, $X$. incisus granulicarpus, Pilumnus villosissimus and Paractaea rufopunctata are found throughout the infralittoral zone on or under rocks. The first 3 species named are very abundant. Dromia personata is common on mid-infralittoral rocky bottoms while Achaeus cranchi is apparently a circalittoral species.

Finally several species live in special habitats. These include Pinnotheres pinnotheres in the mantle cavity of Pinna, P. pisum in the mantle cavity of other bivalves and Planes minutus which lives on floating weed, marine turtles and flotsam. Two pelagic species, Polybius henslowi and Portunus hastatus are also occasionally found in Maltese waters.

\section{ACKNOWLEDGEMENTS}

We should like to express our gratitude to the following persons for help received during the preparation of this report: M. Briffa, J. L. Cilia; G. Lanfranco and M. Micallef for putting their collections of Maltese crabs at our disposal and allowing us to report their records; J. A. Vella Gaffiero for allowing us to examine the specimens of Callinectes sapidus under his care at the National Museum of Natural History. Mdina; Dr. G. Zammit Maempel for information about this species; Dr R. W. Ingle (British Museum Natural History) for identifying part of our material and Dr. R. Agius, G. Bonnet, J. L. Schembri, S. P. Schembri, J. Sciberras, and B. Warrington for collecting specimens.

\section{REFERENCES}

Agius, C., Schembri, P. J. \& Jaccarini, V. (1977) A preliminary report on organisms fouling oyster cultures in Malta (Central Mediterranean). Mem. Biol. Mar. Oceanogr. n. ser. $7(3 / 4): 51-59$. 


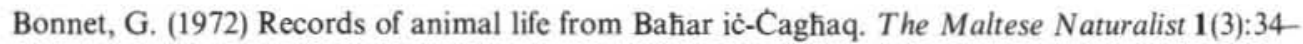
40.

Bouvier, E. L. (1940) Décapodes marcheurs. Faune de France 37 pp. 1-404 + plts.1-XII.

Chace, F. A., (1951) The oceanic crabs of the genera Planes and Pachygrapsus. Proc. U.S. Nat. Mus. 101:65-103.

Costa, M. R. (1982) Some observations on crabs of the genus Planes Bowdich, 1825. Quad. Lab. Tecnol. Pesca, 3(2/5):267-270.

Despott, G. (1930) Ichthyological and carcinological notes. Archivium Melitense 8(2):43$50+$ plts. II-V.

Drach, P. \& Forest, J. (1953) Description et répartition des Xantho des mers d'Europe. Arch. Zool. Exp. Gén. 90:1-36.

Gulia, Gavino (1858-59) Repertorio di storia naturale. Malta: i-iii + 246pp.

Gulia, Gavino (1873) Fauna Maltese: Indice dei crostacei. Il Barth 15/16:314-315.

Gulia, Giovanni (1889-90) Prontuario di storia naturale, contenente la nomenclatura scientifica coi corrispondenti vocabuli italiani e inglesi degli animali e delle piante che sono conosciute sotto una denominazione maltese. Malta:A. Puglisevich, 70pp.

Holthuis, L. B. \& Gottlieb, E. (1958) An annotated list of the decapod Crustacea of the Mediterranean coast of Israel, with an appendix listing the Decapoda of the eastern Mediterranean. Bull. Res. Council Israel sect. B. Zool. 7:1-126.

Ingle, R. W. (1980) British crabs. Oxford \& London: Oxford University Press \& British Museum (Nat.Hist.), 222pp.

Lanfranco, E. (1979) Maltese crabs. Potamon 3:27-28+ plt.II.

Lanfranco, G. (1954) Introducing Malta's Crustacea [part 1]; Crustacea in Malta [parts 2-5]. Times of Malta $10.8 .54 ; 17.8 .54 ; 24.8 .54 ; 31.8 .54 ; 14.9 .54$.

Lanfranco, G. (1957) Il-familja tal-granči fil-bahar tagћna. Pronostku Malti 1957:129-136, [in Maltese].

Lanfranco, G. (1973) Notes on some sedentary invertebrates in Maltese waters. The Maltese Naturalist 1(4):26-28.

Manning, R. B. \& Froglia, C. (1982) On a collection of decapod Crustacea from southern Sardinia. Quad. Lab. Tecnol. Pesca. 3(2/5):319-334.

Manning, R. B. \& Holthuis, L, B. (1981) West African brachyuran crabs (Crustacea:Decapoda). Smithsonian Contrib. Zool. 306 pp. 1-379.

Medlycott, W. C. P. (1870) Appendix X. Notes on the geology, botany and natural history of Malta. pp. 335-355. In: H. Sedall, Malta: Past and present, being a history of Malta from the days of the Phoenicians to the present time. London: Chapman \& Hall, 355pp.

Micallef, H. \& Evans, F. (1968) The marine fauna of Malta. Malta: Malta University Press, vi +26pp. [reprinted in: Roy. Univ. Malta Contrib. Mar. Sci. 1:143-172 (1974)]

Schembri, P. J. \& Jaccarini, V. (1978) Some aspects of the ecology of the echiuran worm Bonellia viridis and associated infauna. Mar. Biol. 47:55-61.

Seguin, G. (1968) Contribution a l'etude quantitative du zooplankton de Malte. Pelagos Bull. Inst. Oceanogr. Alger 10:109-132.

Śtevčić, Z. (1979) Contribution a la conaissance des crustaces decapodes de Malta. Rapp. Comm. Int. Mer. Medit. 25/26(4):127-128.

Tallack, W. (1861) Malta under the Phoenicians, Knights and English. London: A. W. Bennet, $322 \mathrm{pp}$.

Zariquiey Alvarez, R. (1968) Crustáceos decápodes Ibéricos. Inv. Pesq. 32 pp.i-xvi, 1-510. 